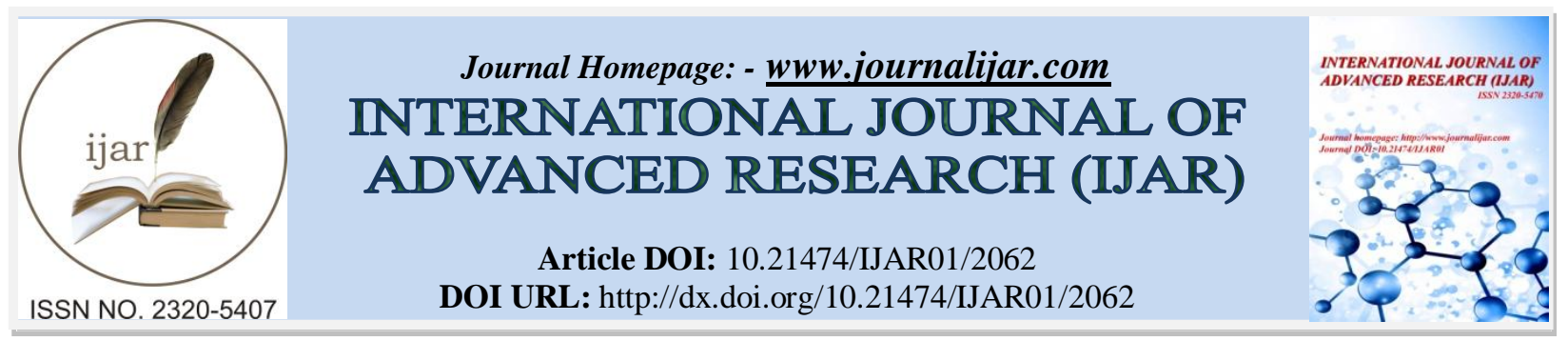

RESEARCH ARTICLE

\title{
VALIDATION OF INTERNATIONAL TRADE DRIVEN GROWTH BY ESTIMATING MARSHALL- LERNER CONDITION BETWEEN INDIA AND SAARC (1997-2015) : AN EMPIRICAL STUDY.
}

Ph.d Economics Scholar, Amity University.

2. Former HOI, Amity School of Economics, Amity University.

\section{Manuscript Info}

Manuscript History

Received: 23 September 2016

Final Accepted: 25 October 2016

Published: November 2016

Key words:-

Bilateral Trade, India, J-curve, MarshallLerner, SAARC.

\section{Abstract}

This paper aims at scrutinizing and providing a validation of the bilateral trade of India with other SAARC countries. India enjoys a dominant share of $70 \%$ area and population among the SAARC countries thus paving way to a great intensity of trade between India and SAARC. Further acceleration to this trade is provided by the 1991 reforms of India, the two trade agreement of SAARC namely SAPTA and SAFTA. Hence, this paper attempts to understand the trade growth pattern of India with respect to its bilateral trade with SAARC by estimating the Marshall-Lerner Condition and the J-curve. For the clear understanding of the effect of SAPTA and SAFTA, the total trade pattern is estimated for 2 times periods 1997-2005 and 2006 2015. In order to analyze the above said, the annual data of five variables namely total exports, total imports; exchange rate, domestic income of India and other SAARC (in totality) are taken from the World Bank. The analysis is done using the modern econometric techniques of Stationarity and Cointergation and OLS method to determine the elasticity using SAS. This study concludes that Marshall-Lerner Condition is satisfied in the case of bilateral trade between India and SAARC. Also, the J-curve pattern is observed. Therefore, this paper serves as a trademark improvement in the field of economics and trade and provides impetus towards future research on which the policies can be adopted in India and this will be helpful for the international trade driven growth and development.

Copy Right, IJAR, 2016,. All rights reserved.

\section{Introduction:-}

In today's world the problem of depression and recession is faced by not only the developing countries but also by the developed countries. As a result of which there occurs deficit in the Balance of Payment. Marshall- Learner has given the most useful insight on how can the Balance of Payment be improved in such situation. Therefore, this paper aims to analyze the economies of SAARC countries in the light of Marshall-Lerner Condition:

$E^{x} d+E^{m} d>1$

This condition says that if the sum of price elasticity of demand $\left(\mathrm{E}^{\mathrm{x}} \mathrm{d}\right)$ for export and price elasticity of demand for import $\left(E^{\mathrm{m}} \mathrm{d}\right)$ is greater than 1, only then the Balance of Trade will improve with the depreciation of the currency. This condition tells us whether the foreign exchange market is stable or unstable. 
1. If this equation is satisfied then the foreign exchange is stable $\left(E^{x} d+E^{m} d>1\right)$ and the BOP will improve with the depreciation of the currency

2. If this sum is less than 1 then the market is unstable $\left.\left(E^{x} d+E^{m} d<1\right)\right)$ and the BOP will deteriorate with the depreciation of the currency

3. If it is equal to 1 , then the change in exchange rate will leave the Balance of Payments unchanged. ( $E^{x} d+E^{m} d$ $=1)$

However, the overall effect of the devaluation or the depreciation has an effect on the BOP of a country in three ways:

1. The imports become costlier and so their volume reduces

2. The exports are encouraged as they become cheaper for the rest of the world

3. Lesser foreign currency is earned by a given quantity of exports

Therefore, the ultimate effect depends upon how the imports and exports of a country respond to the depreciation which in turn depends upon the import and export demand elasticity. So, any combination of export and import elasticity that satisfies the Marshall-Lerner condition will cause the first two effects described above to outweigh the third, leading to an improved trade balance.

The liaison of exchange rate and trade balance is an imperative basis for the foreign policy of any country. Hence, exchange rate and trade balance can to a great extent be explained by Marshall-Lerner condition and J-curve. Majority of the studies assessing the impact of currency depreciation on the external account of a country have focused on the well known Marshall-Lerner condition, which is a long run effect and the J-curve which is the graphical representation of the response of trade balance towards the changes in the exchange rate.

J-curve shows the balance of trade pattern of a country with the time period. In the following figure 1.

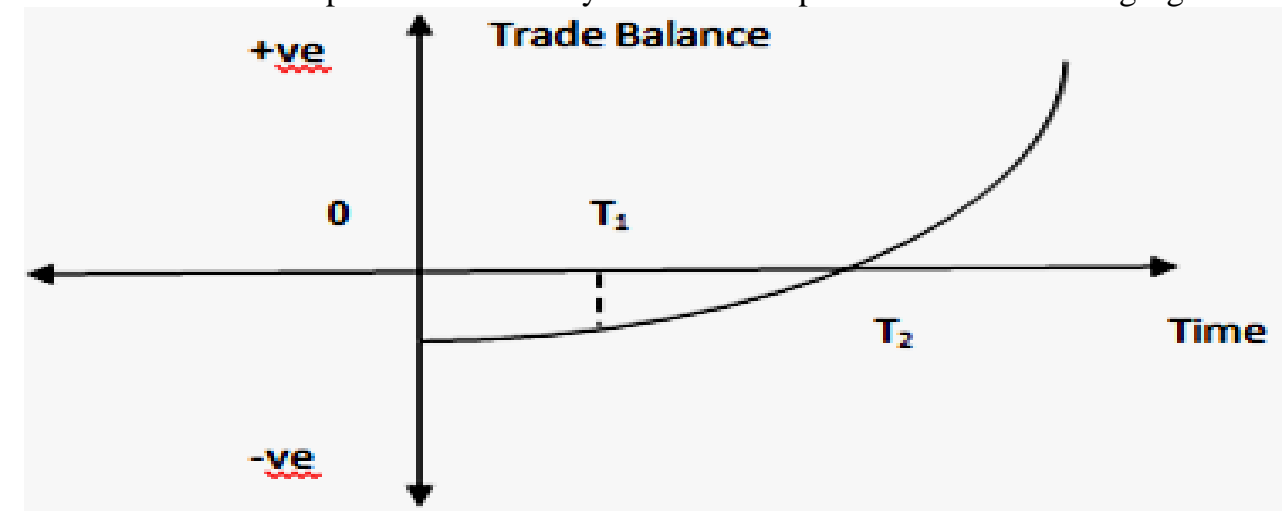

a. Upto $\mathrm{T}_{1}$, the BOP worsens

b. After $T_{1}$, BOP starts improving

c. At $\mathrm{T}_{2}, \mathrm{BOP}$ deficits becomes zero

d. After $\mathrm{T}_{2}$, Bop starts improving and becomes positive.

So, as visible in the diagram above, when the real depreciation of the currency takes place, the BOT will worsen for short- period but eventually the BOT will improve.

\section{Section 1.1 SAARC Economy Trends}

The South Asian Association for Regional Cooperation (SAARC) is an economic integration and geopolitical organization of eight countries and established in December 1985. These countries are primarily located in the South Asia or the Indian Sub-continent. The member countries of the SAARC are India, Pakistan, Bangladesh, Sri Lanka, Nepal, Maldives, Bhutan and Afghanistan. The SAARC secretariat is situated in Kathmandu, Nepal.

The collective economy of SAARC is the $3^{\text {rd }}$ largest in the world in the terms of real GDP subsequent to the U.S and China and $5^{\text {th }}$ biggest in terms of nominal GDP. SAARC nations comprise $3 \%$ of the world's area and contains $21 \%$ (1.7 billion) of the world's total population and around 9.12\% of global economy as of 2015. (Antriksha Negi, 
Feb 2016). SAARC is also home to world's $8^{\text {th }}$ largest economy in the world in GDP (Nominal) terms as well as world's fastest growing economy, that is India. India makes up over $70 \%$ of the area and population among these eight nations. (SAARC official website).During 2005-2010, the average GDP growth rate of SAARC stood at impressive $8.8 \%$ p.a., but it slowed down to $6.5 \%$ in 2011 majorly because of global economic slowdown. However, South Asia once again became the fastest growing region in the world as a result of the strong expansion in India coupled with favorable oil prices, from the last quarter of 2014. As of 2015, foreign exchange reserves of the SAARC nations stand at USD 411 billion. (Pratiyogita Darpan, International Politics Article, 2016)

All the SAARC countries are linked together geographically, historically and culturally even before the formation of this Corporation; especially India and other countries. Among the eight member states, India is in a pre - eminent position in terms of area, population and military strength. Therefore, any policy in India will also have an impact on other SAARC countries' economies:

a) Pakistan was part of British India till 1947.

b) Bangladesh was a part of Pakistan till 1971.

c) All countries except Nepal and Bhutan were under British colonial rule till they got independence.

d) Sri Lanka is only 30 miles away from Indian shores.

e) Nepal is geographically, historically and culturally lined with India.

f) Bhutan is guided by India in its foreign policy since 1949 .

g) Maldives is a tiny island with a population of 2 lakhs and it has a history of Trade with India.

Moreover, these countries have an almost similar demand pattern due do the similar geographical area. They are all the developing countries (IMF, World Economic Outlook April, 2015) and face similar problems like India which are declining prices of number of commodities, turbulent financial markets and volatile exchange rates (PHD Chamber Report on Budget, 2016-2017).

Hence, the correlation between India's trade with SAARC and Indian growth is on the rise significantly. Therefore, it becomes essential to study this trade pattern.

Section 1.2 Trade Agreements between SAARC countries

There are various agreements that have taken place among the member states of the SAARC but the two main trade agreements which had a huge impact on the international trade are as follows:

SAARC Preferential Trade Agreement (SAPTA, 1997):-

In December 1991, the Sixth Summit held in Colombo approved the establishment of an Inter-Governmental Group (IGG) to formulate an agreement to establish a SAARC Preferential Trading Arrangement (SAPTA) by 1997. The Agreement reflected the desire of the Member States to promote and sustain mutual trade and economic cooperation within the SAARC region through the exchange of concessions. The basic principles underlying SAPTA are:

1. overall reciprocity and mutuality of advantages so as to benefit equitably all Contracting States, taking into account their respective level of economic and industrial development, the pattern of their external trade, and trade and tariff policies and systems;

2. recognition of the special needs of the Least Developed Contracting States and agreement on concrete preferential measures in their favor; and

3. inclusion of all products, manufactures and commodities in their raw, semi-processed and processed forms.

Hence, in this study the emphasis has been given on the analyzation of the Bilateral Trade between India and SAARC (1997-2014). The results display an increment of $1090.36 \%$ growth.

\section{South Asia Free Trade Agreement (SAFTA, 2006):-}

The SAFTA Agreement was signed on 6 January 2004 during Twelfth SAARC Summit held in Islamabad, Pakistan. The Agreement entered into force on 1 January 2006, and the Trade Liberalization Programe commenced from

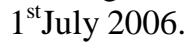

Following the Agreement coming into force the SAFTA Ministerial Council (SMC) has been established comprising the Commerce Ministers of the Member States. To assist the SMC, a SAFTA Committee of Experts (SCOE) has been formed. SCOE is expected to submit its report to SMC every six months. The SAFTA Agreement states that 
the "the SMC shall meet at least once every year or more often as and when considered necessary by the Contracting States. Each Contracting State shall chair the SMC for a period of one year on rotational basis in alphabetical order."

In order to understand the effect of this agreement, the total trade has been analyzed graphically from 1997-2005 and from 2006 -2014 for the bilateral trade between India and the other SAARC countries which shows that the trade increased from (1997) 1966.69 USD million to (2005) 5603. 31 USD million and from (2006) 6960.96 USD million to (2014) 23410.88 USD million.

The member nations of the SAARC countries have undergone a lot of transformation from 1962 onwards and the economy has become more dynamic in the recent years. There are various trade policies and reforms undertaken in these countries and all of them focusing on the openness of trade which have led to the increase in the total trade. However, in the scenario of global slowdown (2007), the trade open countries are also effected severely. The depreciation of the domestic currency can be the rescue if the Marshall-Lerner Condition is satisfied.

Some of the major trends and reforms undertaken by the SAARC countries are as under:

1. Afghanistan : It was included in SAARC in 2007. Thereafter, it became more trade open as a result of the agreement SAFTA (2006).

2. Bangladesh: It adopted the trade reforms in 1990s which included substantial reduction and rationalization of tariffs, removal of quantitative restrictions, as a result the trade integration (trade-GDP) increased from 18\% (1990) to 43\% (2008). (World Bank Report, 2014). It attained independence in 1971.

3. Bhutan: It adopted the trade liberalization scheme under the agreement of SAPTA and others and it has evolved from a closed economy to a trade openness index of $75 \%$ in 2005 and now the trade sector is the highest contributor to the national revenue (Asia Trade Hub Report, 2014).

4. India : The major trade reforms adopted were LPG in 1991 and also the collaboration with the SAARC in 1985 and trade agreements SAPTA (1997) AND SAFTA (2007) has led to increase in the trade.

5. Nepal : It is among the most open and trade dependent economy in the South Asia. Exports have been growing since 1990s with some exceptions. Also, it completed its accession to WTO and became $147^{\text {th }}$ member in 2004). It was the first LDC to be part of the multilateral trade regime. (World Bank Report, 2014) It is also part of SAARC since 1985.

6. Pakistan : The bulk of its trade is with the South Asia countries. However, it had made a substantial progress in constructing a more open and transparent trade policy regimes by adopted various measures such as reducing tariff rates in 2005 to about $50 \%$ as compared to 1995 , quantitative restrictions have largely been eliminated. It has been part of trade agreements such as SAFTA (2006) and SAPTA (1997).

7. Sri Lanka : It began the trade liberalizing policy in the 1970s, which is well-ahead as compared to other SAARC countries. Hence, the trade integration (trade-GDP) is 82\% of GDP in 2004 (World Bank Report, 2014).

The objectives of the study are as follows:

1. To estimate the growth in the total trade between India and other SAARC countries over the period 1997-2015.

2. To empirically estimate the Marshall-Lerner Condition of the trade between India and SAARC (2004-2013)

3. To analyze the J-curve pattern between India and SAARC (1997-2015)

\section{Section 2 Literature Review:-}

The empirical assessment of these conditions encompasses a wealthy heritage and numerous studies have attempted to find the nature of the relationship between exchange rate volatility and trade. The studies conducted in the $18^{\text {th }}$ and $19^{\text {th }}$ century mainly used the least square methods to guesstimate price elasticities in import and export equations and they bent mixed results (Khan 1974, Goldstein and Khan 1985, Wilson and Takacs 1979, Warner and Kreinin 1983, Bahmani-Oskooee 1986, Krugman and Baldwin 1987). However, these theories are mainly criticized because they did not check the stationarities of the data and hence the result seemed to be biased.

Therefore, later, the econometric techniques implying non-stationarities and reduced-form equation in the data has been used and most of the studies resulted to support the ML condition (Bahmani-Oskooee 1998, Bahmani-Oskooee and Niroomand 1998, Caporale and Chui 1999, Boyd, Caporale and Smith, 2001).

A vast review of literature has been done to understand the work done in this vital field. A broad-spectrum acuity is that a nominal devaluation can trim down trade imbalances only if it translates into a real one and if trade flows respond to relative prices in a momentous and conventional manner (Reinhart, 1995). A devaluation of the domestic 
currency will be lucrative and beneficial for the economy by escalating the global competitiveness of domestic industries (Kandil and Mirazaie, 2005). Dornbusch (1988) shows that the efficacy of depreciation in improving the balance of payments depends on redirecting demand in the right direction and by the correct amount and also on the capacity of the domestic economy to meet the additional demand through increased supply. Bird (2001) argues that if inflation is on acceleration, then there is no course of action to keep the real exchange rate in equilibrium. Therefore, in his outlook, several developing countries have selected flexible exchange rates but this is not an idyllic elucidation since demand and supply elasticities may be fairly low: even when they satisfy the Marshall-Lerner conditions, their response to exchange rate changes may not be as big as in developed economies. The research so far done on the developing and developed countires are included in this paper and discussed here. By reviewing these studies no definite conclusion can be drawn for developing countries.

Eita, Joel Hinaunye (2013) finds evidence in favour of Marshall-Lerner condition for Namibia using a cointegration model and also estimates income elasticities of trade for the country. The time-series data were not tested for the stationarity. Prior to that Judith Olivia Canipe (2012) conducted a study in Ghana to test the ML condition prior to 1983 using OLS and panel regressions and the theory was not agreed upon. Also, the data were not tested for the basic properties of the time-series and thus the results are not reliable. In the same year, one more study was undertaken by Başak Gümüştekin(2012) enquire the existence of the effect of devaluation on the trade balance both for the long run as well as the short run for a period of 22 years which included 20 industries using the co integration and error correction modeling. The result does not strongly favor the ML condition. The main limitation noticed here is that only specific industries have been studied by them which does not bring out a clear and broad picture of a country as a whole.

Adnan Ali Shahzad (2013) tried to estimate the relationship between the real exchange rate and the balance of trade for the selected South Asian countries. The study used panel unit root test and Pedroni cointegration test. The study found no evidence for the satisfaction of the condition. In order to test the ML condition in Nigeria Unit root tests (ADF and PP), Johansen an Juselius approach to estimation of multivariate cointegration system and ordinary least square (OLS) were used. The results show the evidence to support the theory. This was also undertaken by the same economist. ML condition was tested for the Kenyan economy for the period 1996 to 2011 by using the quarterly data on the log of real exchange rates. In particular, fractional integration and cointegration methods were used by Robert Mudida (2012). The study concluded of a well defined relationship and agreed with the ML condition $\mathrm{n}$ for the long run.

A study was conducted in Pakistan with time series quarterly data for 12 major trading partners for 5 years by Aftab and Khan (2008). It used unit root test and ARDL model. It stated no evidence in support of the theory. However, the time period taken is too short to have robust estimates.

In the recent past, various research work has been done in Pakistan but the theories have somehow lacked to provide broad information. A recent study by Awan et. al. (2012) estimated the impact of currency depreciation on balance of trade in the long run but didn't find any empirical evidence in favor of J-curve phenomenon in Pakistan. On the same grounds, a model considering the strategic framework of liberalizing trade in services for Pakistan a concluded that the Marshall-Lerner condition is satisfied for non-tradable goods(Ahmed Gulzar, 2011). However, this study cannot be regarded to be complete because it focused only on the non-tradable goods which does not provide the clarity of the scenario.

Bahmani-Oskooee and Cheema (2009) tried to estimate for Pakistan by using disaggregated quarterly data and found no significant pattern of the J-curve. Zehra Aftab and Aurengzeb,2002 conducted the study on The Long-run and Short-run Impact of Exchange Rate Devaluation on Pakistan's Trade Performance(1980-2000) in which they tested the model using regional data consisting of seven Asian Developing Countries, namely, Fiji, India, Malayasia, Maldives Philippines, Sri Lanka, and Thailand. They assumed that the world supply of imports to Pakistan is perfectly elastic which is too simplistic assumption to have the real time estimates. The results were satisfactory for the condition.

Bahmani-Oskooee (1985) used quarterly data and Almon lag structure for 7 years to estimate the ML condition in 4 developing countries. The result satisfied the J-curve and ML condition but it is criticized on the point that it did not check the data for the stationarity and therefore the result may be biased. However, this shortcoming has been later covered by other economists. Lal and Lowinger (2002) conducted a study for the selected South Asian countries 
where the data was tested for stationarity and used Johansen Multivariate Cointegration and Error Correction Model (ECM) approach. This study supported the ML condition. But, the greatest shortcoming is that this study has used individual analysis on a region instead of regional analysis. When the work done in Sri Lanka was reviwed, two important studies are worth discussing here. Perera (2011) and Alawattage (2002) examined the relationship between real exchange rate depreciation and trade balance for Sri-Lanka and rejected the J-curve phenomenon. Aftab and Khan (2008) empirically tested the presence

J-curve pattern between Sri-Lanka and her 6 trading partners. Unlike the previous study Augmented Dickey-Fuller test was used and then employed ARDL model to estimate the short run and long run relationship between balance of trade and exchange rate depreciation. Here also, like the case in Pakistan no significant pattern was found but this may be because instead of aggregate data, bilateral data was used. India was not taken as one of the trading partner.

Alam (2010) estimated the ML condition for the Bangladesh. The study like many others used the time series data which was first tested for cointegration and then was estimated using Granger Causality tests. This showed no defined relation between the variables.A study was conducted on Trade Pattern in SAARC Countries: Emerging Trends and Issues (Rajeev Jain and J. B. Singh,2009) focusing on the analysis of South Asia Association for Regional Co-operation (SAARC) trade, this paper attempted to explore the merchandise trade performance of SAARC region and also the inclination in intra-SAARC trade. A concise analysis of trade baskets of SAARC countries showed that export baskets of major SAARC countries are radically analogous reflecting that they may be competing with one another in same industries in the international market. But this study did not focus on the elasticity approach that is Marshall-Lerner condition and the J-curve.

An important study worth mentioning is by Prof. Kulkarni (2004) which is about he J-curve hypothesis and the currency devaluation. He depicted the shifts in the J-curve because of the continuous devaluation in the case of the flexible exchange rates. This shifting pattern is depicted by him in the study conducted for Ghana (1983-1989).

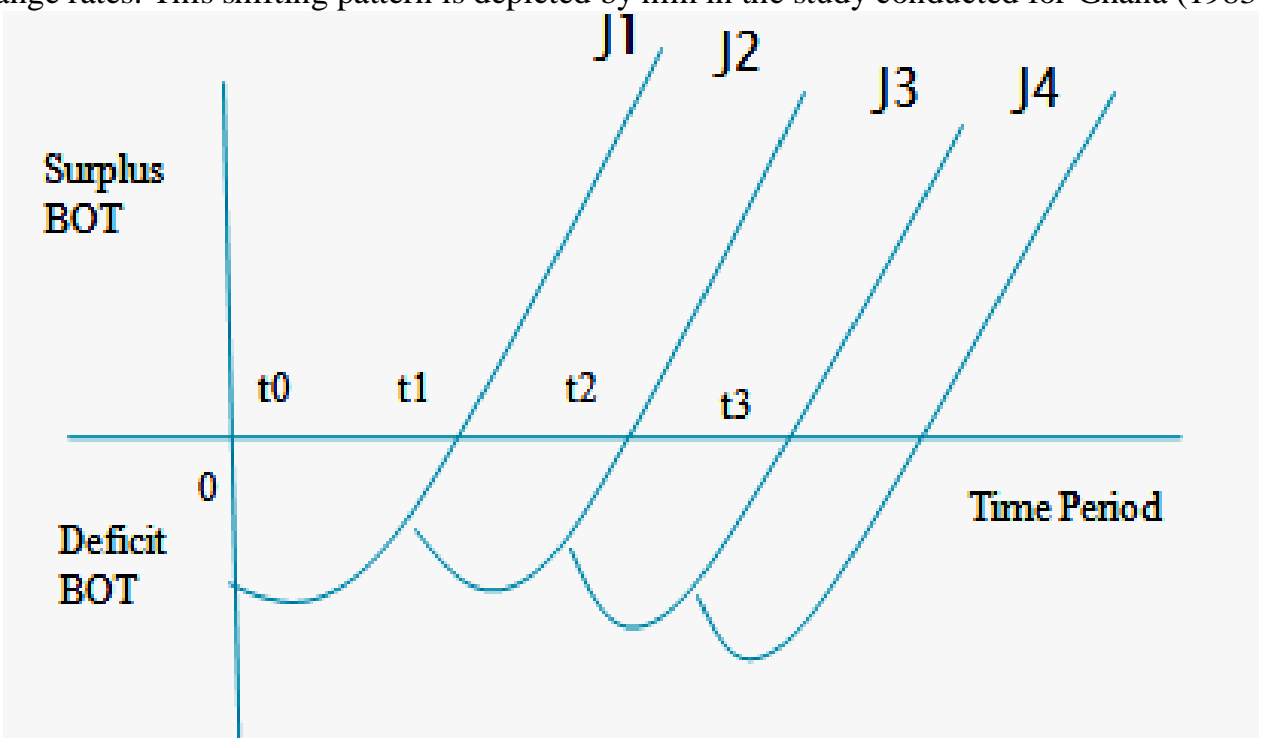

This is because when a country allows to devalue a currency several times, then the shifts of the J-curve becomes more relevant, then a persistent balance of trade deficit is a very likely outcome.

In the figure 2 shown, there are four devaluations taking place at the time period $\mathrm{t} 0, \mathrm{t} 1, \mathrm{t} 2$ and $\mathrm{t} 3$. This shifts the $\mathrm{J}$ curve further to the right and there are four J-curves observed namely J1, J2, J3 and J4.

A relevant argument in favor of J-curve hypothesis is that devaluation of a currency required time lags before improving the trade balance in less developed countries, which support the pattern of movement describe by the Jcurve (Oskooee, 1985). Rincon and Nelson (2001) also found the strong indication in favor of J-curve hypothesis for small semi-open economies. Depreciation of domestic currency worsens the balance of trade in the short run but get better it in the long run. The existence of M-L condition fulfills in the long run and degree of J-curve hypothesis effects in the short run in East Asia (Onafowora, 2003). 
On the other side, some arguments are going against the J-curve hypothesis. Currency devaluation adjusts the balance of trade through import compression and export expansion. A study of 34 developing countries rejects this hypothesis. Imports of these countries are used as inputs into the production of exports. Thus, import compression has as adversely affected on export expansion (Khan and Knight, 1988). An earlier study by Rose and Yellen (1989) examined the relationship between exchange rate depreciation and balance of trade. The study found that trade balance of G-7 countries does not follow the J-curve pattern. Rose (1990) worked on a sample of developing countries to estimate the impact of exchange rate changing on trade balance and concluded that J-curve hypothesis does not exist. Akbostanci (2002) estimated the performance in trade balance in response to real exchange rate depreciation and found no empirical indication which support of J-curve pattern. For instance, a study by Moura and Silva (2005) found no evidence in favor of worsening the trade balance in the short run for Brazil. Alawattage (2002) and Perera (2011) examined the relationship between real exchange rate depreciation and trade balance, and found no empirical confirmation in favor of J-curve phenomenon for the Sri-Lanka. Aftab and Khan (2008) also found no empirical evidence which support the J-curve phenomenon in Pakistan. An important work by BahmaniOskooee and Cheema (2009) found no significant impact on balance of trade as a result of exchange rate depreciation of Pakistan's trade with two large trading partners and found no empirical evidence in favor of J-curve hypothesis. Furthermore, a very recent study by Awan et. al. (2012) estimated the impact of currency depreciation on balance of trade in the long run but didn't find any empirical evidence in favor of J-curve phenomenon in Pakistan.

\section{Section 2.1 Theoretical Model and Concept:-}

Yun Zheng (2012) conducted the study for the bilateral trade between Thailand and the China for the period from 1997-2012. The results concluded that the Marshall-Lerner Condition is satisfied. He used the following model :

- $\operatorname{LnXt}=\alpha+\beta \operatorname{LnYt}$ China $+\gamma \operatorname{LnREX}+\delta \operatorname{LnVOL}+\varepsilon(1)$

- $\operatorname{LnMt}=\alpha+\beta \operatorname{LnYtTH}+\gamma \operatorname{LnREX}+\delta$ LnVOL $+\varepsilon(2)$

Where: $\mathrm{Ln}$ represents natural logarithm, $\mathrm{X}$ is the Thailand aggregate export to China and t $\mathrm{M}$ is the aggregate import by Thailand from China. Model (1) we expect an estimate of $\beta$ to be positive indicating an increase in Thailand export earnings due to increase in GDP of China. Similarly, Model (2) we expect an estimate of $\beta$ ' to be positive due to economic growth in the Thailand. China Y express as gross domestic product of China and TH Y express as gross domestic product of Thailand. $t$ REX is bilateral real exchange rate. REX is constructed with the Thailand and China Consumer Price Indices. t VOL is the volatility of the bilateral real exchange rate and $\varepsilon$ is a disturbance term.

This model represents too much of simplicity with expecting $\beta$ to be positive as increase in any country's export earnings due to increase in trading country's GDP is not necessary.Also, in this model, the REX is calculated using the Consumer Price Indices whereas the actual exchange rate will depict robust results. Although the series are converted in LOG but that just solves the purpose of making the time-series normal and the series are not tested for stationarity and co integration which is necessary to have robust estimates.

Zehra Aftab and Aunrangzeb(2002) conducted the study on the Long run and Short run impact of Exchange Rate devaluation on Pakistan's Trade performance. They used quarterly data to analyse the trade elasticites and analyze the Marshall-Lerner condition for the trade between the Pakistan and its 10 trading partners (1980-2000). The Jhonsen's cointegration methodology and the OLS has been used. The following model has been used :

$\log \mathrm{Mt}=\alpha 1+\alpha 2 \log \mathrm{RPMt}+\alpha 3 \log \mathrm{Yt}+\varepsilon 1 \mathrm{t}$

$\log \mathrm{Xt}=\beta 1+\beta 2 \log \mathrm{RPXt}+\beta 3 \log \mathrm{YWt}+\varepsilon 2 \mathrm{t}$

It is assumed that the world supply of imports to Pakistan is perfectly elastic:-

Where, M is the real quantity of total imports; RPM is the relative prices defined as the ratio of import prices to domestic price level; $\mathrm{Y}$ is the gross domestic product at 1995 prices, and $\varepsilon 1 \mathrm{t}$ is the random disturbance term. $\mathrm{X}$ is the real quantity of total exports; RPX is the relative price of exports defined as the ratio of domestic export prices to the price of average exports of the major trading partners, YW is the average of the Gross Domestic Product of major trading partners, and $\varepsilon 2 t$ is the random disturbance term. The results were satisfactory for the condition.

In this model, the series are not tested for statioanrity, although they are tested for the Cointegration. Moreover, the Relative Price is taken as the ratio between the prices at the domestic and the international level. Exchange rate is completely avoided. 
Rustam Jamilov (2011) “ J-Curve Dynamics and the Marshall-Lerner Condition: Evidence from Azerbaijan “ from 2006 to2009.

- $\ln (\mathrm{Xt})=\alpha 0+\beta \mathrm{x}(\mathrm{RFXt})+\beta \mathrm{eur}(\ln$ Yeur $)+\varepsilon t(1)$

- $\ln (\mathrm{IMt})=\alpha 0+\beta \mathrm{im}(\mathrm{RFXt})+\beta \mathrm{az}(\ln \mathrm{Yaz})+\varepsilon \mathrm{t}(2)$

where, $\ln$ is the natural logarithm, $\mathrm{X}$ and IM are the values of non-oil exports and imports respectively, RFX is the real bilateral exchange rate, Yeur is the Industrial Production Index of the Eurozone, Yaz is the real GDP of Azerbaijan, and $\varepsilon t$ is the error term. Therefore, according to this model setup, a depreciation of Manat should improve the Azerbaijani trade balance in the long run.

Firstly, the time period is really short to conclude findings. Also, the IPI measures the real production output of manufacturing, mining and utilites. It could have been better if the GDP of the Eurozone should be taken in the export equation or IPI could have been taken in the Imports equation to maintain the uniformity and this would have reduced the discrepancies. That could have presented robust and reliable results. Apart from the limitation observed in the variable, another was that coefficient of the RFXT are taken as elasticity. But this is not the measure of elasticity. It further includes one more step.

Two assumptions are taken in the study by Hernán Rincón C (2010) "Testing the Short-and-Long-Run Exchange Rate Effects on Trade Balance: The Case of Colombia " for 10 years . The first assumption is that domestic and foreign nominal incomes are held constant. The second is that "domestic prices" remain constant ("domestic" should be understood as the general domestic price level). This in a away, omits the complete effect of the exchange rate on the exports and the imports. Thus, here also the coefficients are taken directly as the elasticity.

BigBen Chukwuma Ogbonna (2011) examined the impact of currency devaluation on the trade balance of Nigeria for the period $1970-2005$. The study concludes that the Marshall-Lerner Condition does not hold. The model adopted for the research is as follows:

$\mathrm{LB}=\mathrm{a} 0+\mathrm{a} 1 \mathrm{LFY}+\mathrm{a} 2 \mathrm{LDY}+\mathrm{a} 3 \mathrm{LER}$

Where, $\mathrm{L}$ is the natural logarithm, B is trade balance, FY is foreign income (GDP), DY is domestic Income (GDP) and ER is the exchange rate. The coefficient of ER represents the Export Elasticity +Import Elasticity value. This is too simplistic a model. The lags in the export and the import are completely neglected. Thus, the export and import elasticity are hard to understand.

Section 3:- Research Methodology:-

Section 3.1 Identification and Source of Variables

Table 1:- Five variables have been taken in this study which are defined as follows along with the source.

\begin{tabular}{|l|l|l|}
\hline Variable & Data for the variable & Source \\
\hline Exports (X from India) & Total value exports in USD million & $\begin{array}{l}\text { Ministry of Commerce and Industry } \\
: \text { Country -wise trade with India } \\
\text { Databank,2015 }\end{array}$ \\
\hline Imports (Y to SAARC) & Total value imports in USD million & $\begin{array}{l}\text { Ministry of Commerce and Industry } \\
\text { Country -wise trade with India } \\
\text { Databank.,2015 }\end{array}$ \\
\hline Real Exchange Rate (RER) & $\begin{array}{l}\text { Real Exchange Rate in terms of USD } \\
(\$)\end{array}$ & $\begin{array}{l}\text { World Bank Databank of Exchange } \\
\text { Rate,2015 }\end{array}$ \\
\hline Domestic Income (India's GNI) & In terms of USD million (GNI) & World Bank Databank of GNI, 2015 \\
\hline $\begin{array}{l}\text { World Income ( summation GNI } \\
\text { of SAARC) }\end{array}$ & In terms of USD million (GNI) & World Bank Databank of GNI,2015 \\
\hline
\end{tabular}

Section 3.2 Model Creation:-

In order to estimate the Marshall-Lerner Condition by evaluating the export and import elasticity, a Multiple Regression model has been formed with 2 equations of export and import. This model is represented as follows:

$\log X=\beta_{1}+\beta_{2} \log$ WI $+\beta_{3} \log$ RER $+\mu_{1}$-----------to calculate Export Elasticity-----(1)

$\log \mathrm{Y}=\alpha_{1}+\alpha_{2} \log \mathrm{DI}+\alpha_{3} \log \mathrm{RER}+\mu_{2}$--------------to calculate Import Elasticity------(2) 
Equation (1) represents the Export equation where Export (X) is the dependent variable on the World Income (WI) and the Real Exchange Rate(RER) which are the independent variables.

Equation (2) represents the Import equation where Import (Y) is the dependent variable on the Domestic Income (DI) and the Real Exchange Rate(RER) which are the independent variables.

Where,

- $\boldsymbol{\beta}_{1}=$ The intercept coefficient which represents the change in the Exports (Dependent variable) is not dependent on World Income and Real Exchange Rate (Independent variables).

- $\quad \boldsymbol{\beta}_{2}=$ The slope coefficient representing the responsiveness of Exports (Dependent variable ) with the change in World Income (Independent variable).

- $\quad \boldsymbol{\beta}_{3}=$ The slope coefficient representing the responsiveness of Exports (Dependent variable ) with the change in Real Exchange Rate (Independent variable).

- $\boldsymbol{\alpha}_{1}=$ The intercept coefficient which represents the change in the Imports (Dependent variable) is not dependent on Indian Domestic Income (GNI) and Real Exchange Rate (Independent variables).

- $\quad \boldsymbol{\alpha}_{2}=$ The slope coefficient representing the responsiveness of Imports (Dependent variable) with the change in Indian Domestic Income (Independent variable).

- $\boldsymbol{\alpha}_{3}=$ The slope coefficient representing the responsiveness of Imports (Dependent variable ) with the change in Real Exchange Rate (Independent variable).

- $\boldsymbol{\mu}_{1}$ and $\boldsymbol{\mu}_{2}=$ the disturbance term in the export and import equation respectively.

The following steps have been undertaken to analyze the data:

- The data is tested for statioanrity using Unit root test by making use of SAS and it is found that there is stationarity.

- The data is tested for cointegration using Augmented Dickey- Fuller test and it is found that no cointegration exist between the series.

- Finally OLS is done at $95 \%$ level of significance to find the estimates which can are shown in the next section.

Section 4 Data Analysis:-

Table 2:- Stationary Testing For the Bilateral Trade of India with SAARC countries.

\begin{tabular}{|l|l|l|l|}
\hline Variable & Test Statistic & $\mathbf{5 \%}$ Critical Value & Result \\
\hline Exports from India & $\mathbf{3 . 4 0}$ & $\mathbf{3 . 4 1}$ & Stationary \\
\hline Imports to India & $\mathbf{3 . 3 8}$ & $\mathbf{3 . 4 1}$ & Stationary \\
\hline
\end{tabular}

Table 3:- Cointegration Testing For the Bilateral Trade of India with SAARC countries

\begin{tabular}{|l|l|l|l|}
\hline Variables & Test Statistic & $\mathbf{5} \%$ Critical Value & Result \\
\hline Exports Model & -3.45 & -3.34 & No Cointegration \\
\hline Imports Model & -3.77 & -3.34 & No Cointegration \\
\hline
\end{tabular}

Section 4.1 Marshall-Lerner Condition of Bilateral Trade between India and SAARC (2004-2013)

Table 4:- Export Equation (India to SAARC)

\begin{tabular}{|c|c|c|c|c|c|}
\hline \multicolumn{3}{|l|}{ Regression Statistics } & & & \\
\hline Multiple R & \multicolumn{2}{|c|}{0.950518} & & & \\
\hline R Square & \multicolumn{2}{|c|}{0.903484} & & & \\
\hline Adjusted R Square & \multicolumn{2}{|c|}{0.875908} & & & \\
\hline Standard Error & \multicolumn{2}{|c|}{0.067282} & & & \\
\hline \multirow[t]{2}{*}{ Observations } & \multirow{2}{*}{\multicolumn{2}{|c|}{10}} & & & \\
\hline & & & Coefficients & Standard Error & $t$ Stat \\
\hline \multicolumn{2}{|l|}{ Intercept } & & -0.62292 & 0.8414368 & -0.7403 \\
\hline \multicolumn{2}{|c|}{ Log SAARC Domestic Income /World Income } & & 0.149263 & 0.0274176 & 5.44406 \\
\hline \multicolumn{2}{|l|}{ Log Exchange Rate } & & 0.74745 & 0.6488356 & 1.15199 \\
\hline
\end{tabular}




\section{Discussion of Table 4:-}

1. As multiple regressio-ns is 0.95 . So, it indicates that there is a high level of correlation between the dependent (Export of India to SAARC) and independent variables (World Income which is total domestic income of SAARC countries except India and Exchange rate).

2. R2 is 0.90 which is satisfactory fit as it means that $90 \%$ of the variation in Exports of Sugar is explained by the World Income and the Exchange rate.

3. The standard error is coming to be as 0.06 .

4. The ER coefficient is 0.74; it means that for each unit increase in ER (appreciation), the exports increase by 0.74 units.

5. The world income /total domestic income of SAARC coefficient is 0.14 which means that for each unit increase in WI, the exports increases by 0.14 .

Hence, the export equation becomes:

$\log \mathrm{X}=-0.622+0.1492 \mathrm{WI}+0.74745 \mathrm{ER}$

$(0.81) \quad(0.02) \quad(1.15)$

Export Elasticity $=1 / 0.74745=1.33$

World Income Elasticity $=1 / 0.1492=6.702$
1. A $1 \%$ depreciation in the Real Exchange rate causes the exports to decrease by $1.33 \% \%$.

2. A $1 \%$ increase in the world income causes $6.702 \%$ increase in the exports.

Table 5:- Import Equation (India from SAARC)

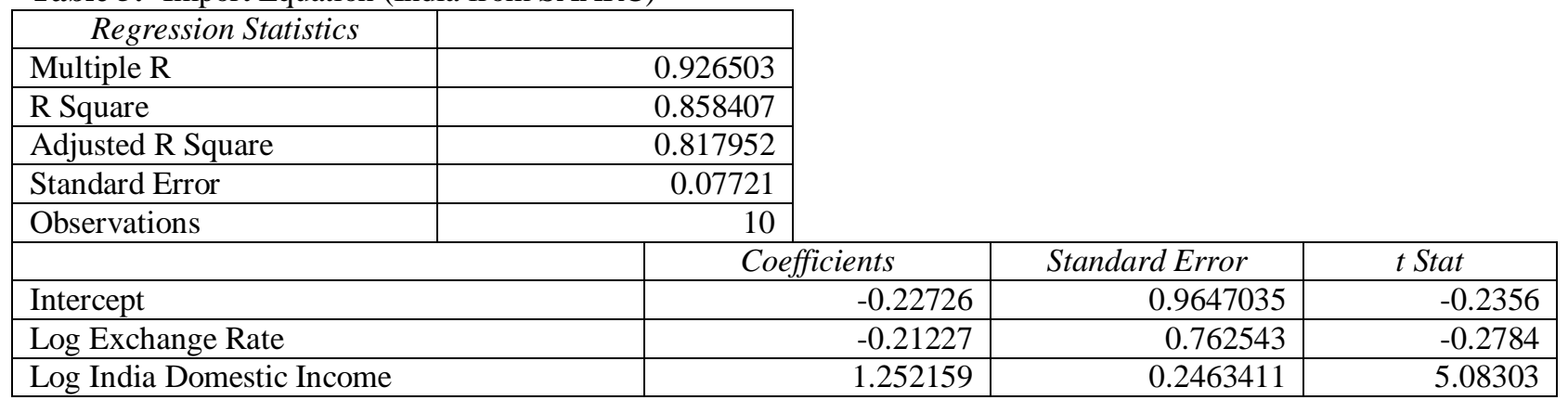

Discussion of Table 5:-

1. As multiple regressions is 0.92 . So, it indicates that there is a high level of correlation between the dependent (Import to India from SAARC) and independent variables (Indian Domestic Income and Exchange rate).

2. $\mathrm{R}^{2}$ is 0.85 which is goodness of fit as it means that $85 \%$ of the variation in Imports is explained by the Domestic Income and the Exchange rate.

3. The standard error is coming to be at 0.07 .

4. The ER coefficient is -0.21 , it means that for each unit increase in ER (appreciation), the imports decreases by 0.21 units . Also the standard error is coming to be too low at 0.76 .

5. The domestic income coefficient is 1.25 , which means that for each unit increase in domestic income of India, the imports increases by 1.25 units. Also, the standard error is coming to be too low at 0.24 .

Hence, the export equation becomes:

$$
\log \mathrm{Y}=-0.22-0.21 \mathrm{ER}+1.25 \mathrm{DI}
$$$$
(0.96) \quad(0.76) \quad(0.24)
$$

Import Elasticity $=1 / 0.21=4.761$

Domestic Income Elasticity $=1 / 1.25=0.8$

Hence, the Marshall-Lerner Condition is Export Elasticity + Import Elasticity $=1.33+4.761=6.091$
1. A $1 \%$ depreciation in the Real Exchange rate causes the imports to increase by $4.761 \%$.

2. A $1 \%$ increase in the domestic income causes $0.8 \%$ increase in the imports. 
Table 6:- Marshall-Lerner Condition of India's bilateral Trade with SAARC (2004-2013) ( Data of all the countries is available from 2004 and the second trade agreement also held this time.)

\begin{tabular}{|c|c|c|c|c|c|}
\hline Equation & Variable & Coefficient & T-stat $(5 \%)$ & Elasticity & $\begin{array}{ll}\mathbf{M} \quad- & \text { L } \\
\text { Condition } & \end{array}$ \\
\hline \multirow{2}{*}{$\begin{array}{l}\text { Exports from India } \\
\mathrm{R}=0.95\end{array}$} & Constant & -0.62 & -0.74 & \multirow{3}{*}{$\begin{array}{l}\text { Export } \\
\text { Elasticity = } 1 \\
/ 0.74745= \\
1.33\end{array}$} & \multirow{6}{*}{$\begin{array}{l}1.33+4.761= \\
6.091 \\
(\text { Satisfied })\end{array}$} \\
\hline & Exchange Rate & 0.74 & 1.15 & & \\
\hline Adjusted $\mathrm{R}^{2}=0.87$ & $\begin{array}{l}\text { SAARC } \\
\text { Domestic } \\
\text { Income }\end{array}$ & 0.14 & 5.44 & & \\
\hline \multirow{3}{*}{$\begin{array}{l}\text { Imports to India } \\
\mathrm{R}=0.92\end{array}$} & Constant & -0.22 & -0.23 & \multirow{3}{*}{$\begin{array}{l}\text { Import } \\
\text { Elasticity = } \\
1 / 0.21= \\
4.761\end{array}$} & \\
\hline & Exchange Rate & -0.21 & -0.27 & & \\
\hline & $\begin{array}{l}\text { Indian } \\
\text { Domestic } \\
\text { Income }\end{array}$ & 1.25 & Section 5.2 & & \\
\hline
\end{tabular}

Section 4.2 : Total Trade Pattern between India and SAARC

After SAPTA (1997-2005):-

Figure 1:- Trade trend of Exports from India to other SAARC and Imports from other SAARC to India (19972005).

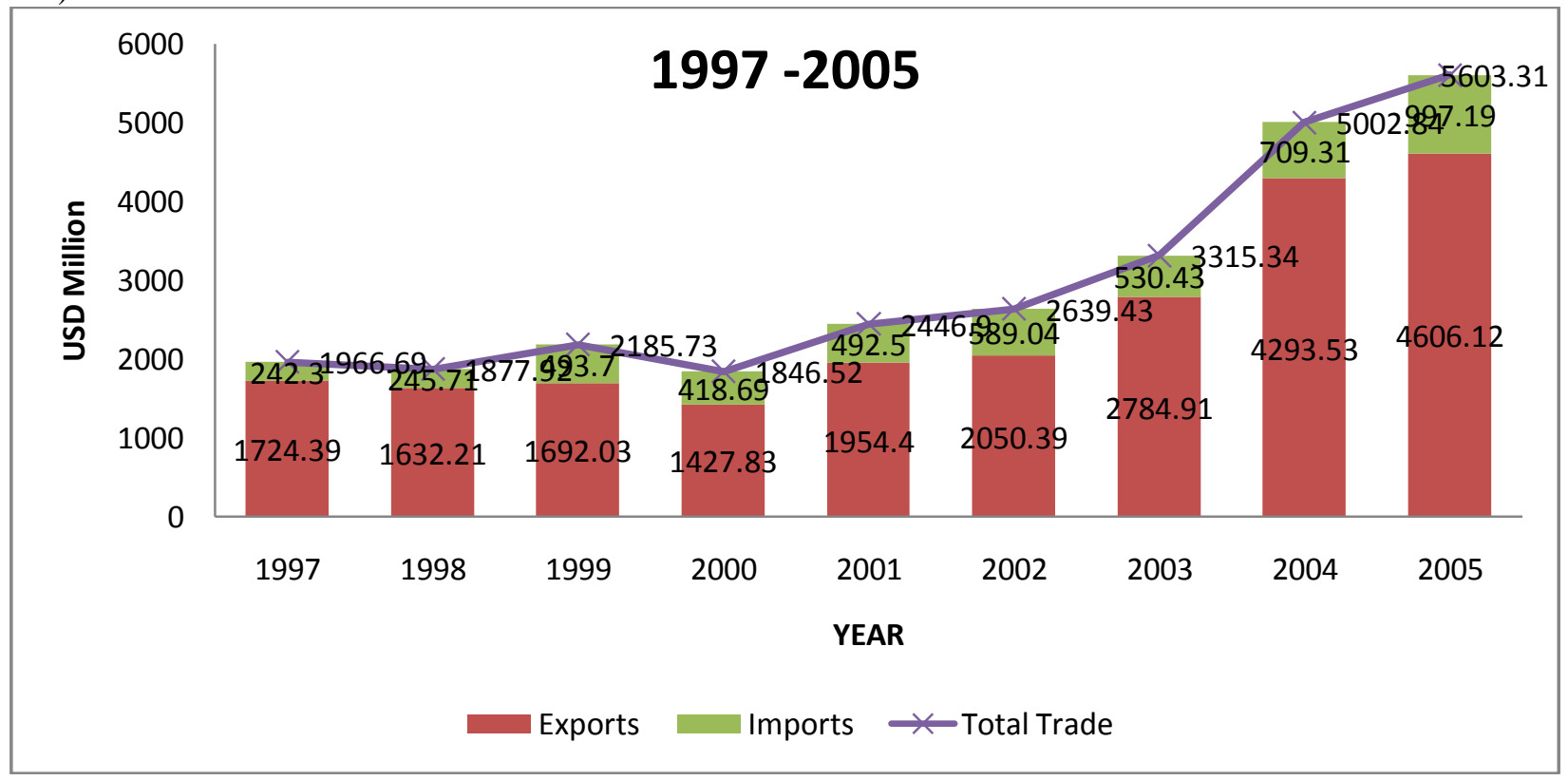


After SAFTA (2006-2015):-

Figure 2:- Trade trend of Exports from India to other SAARC and Imports from other SAARC to India (2006-2015)

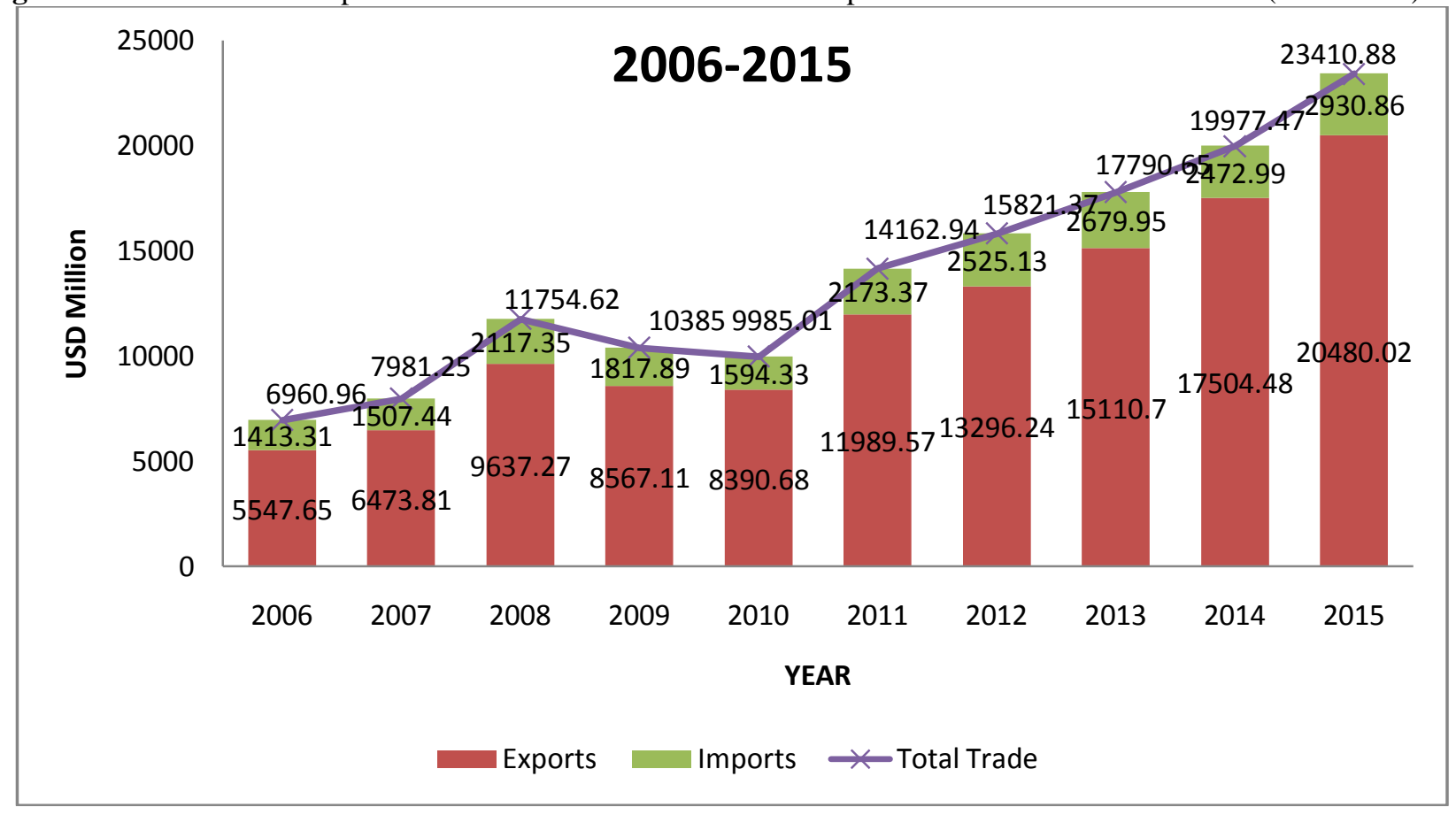


Section 4.3 : J-curve between India and SAARC (1997-2015):-

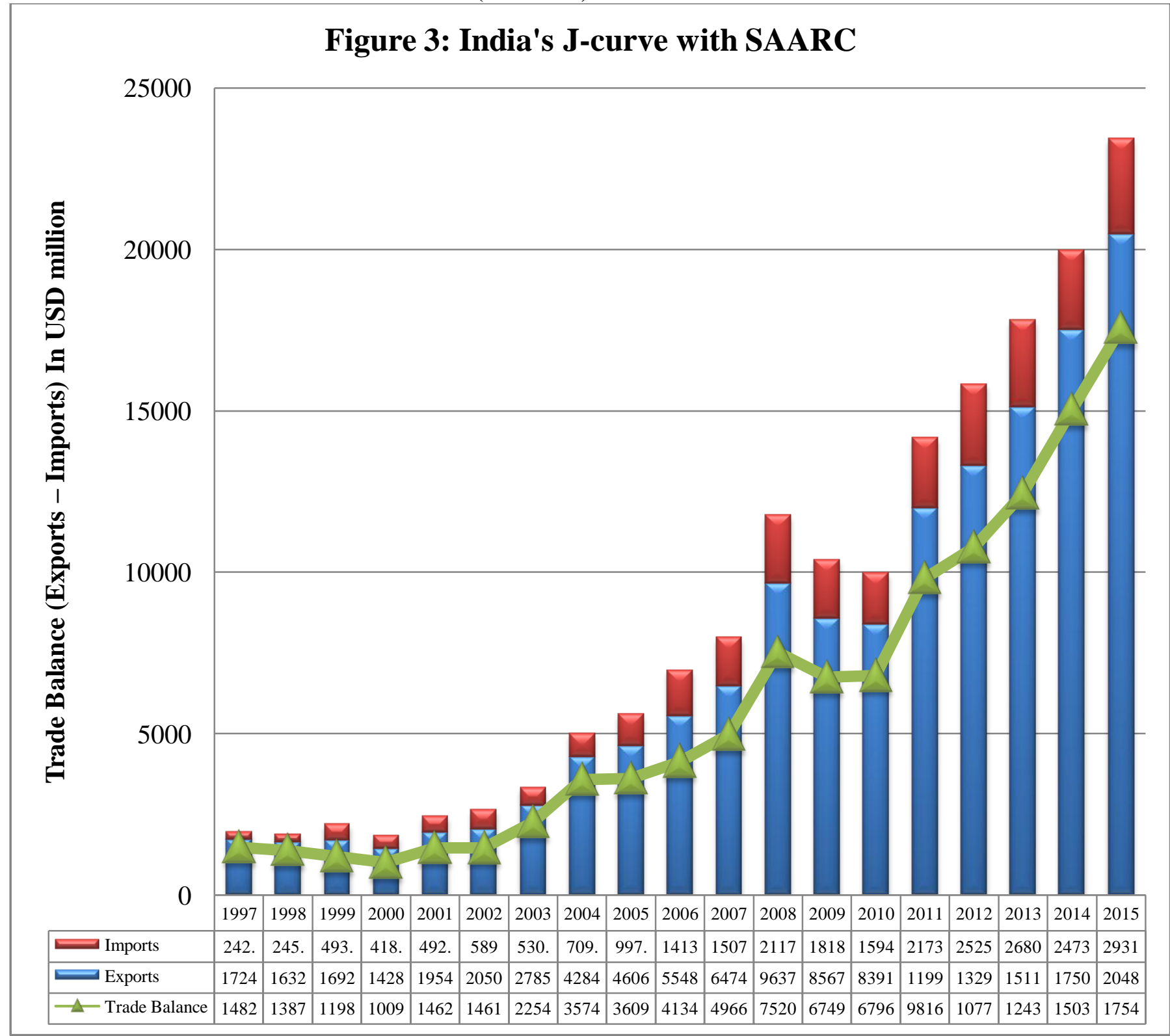

\section{Conclusion and Discussion:-}

After analyzing the India's trade with the other SAARC countries, the following can be concluded:

1. The demand pattern is same in SAARC and thus there is representative demand trade pattern of India with SAARC. India, being at the dominant position, the trade pattern indicates the satisfaction of the Marshall-Lerner Condition of India with the SAARC (Table 6).Thus, devaluation/depreciation will be helpful for India to improve the BOP situation with a major portion from the export to SAARC countries.

2. After the formation of the trade agreements SAPTA (1997) and SAFTA (2006), the trade has increased 184.91 $\%$ from 1997 to 2005 wherein the exports increased by $167.11 \%$ and imports by $311.55 \%$ in the same time period with the depreciation of the India currency from 36.31 USD to 44.09 USD 2009 (World bank data appendix 1).Also, the trade increased $236.31 \%$ from 2006 to 2015 (Figure 2) with exports increasing by $269.16 \%$ and imports by $107.37 \%$ with the depreciation of the Indian currency from 45.30USD to 63.75 USD 2009 (World bank data appendix 1). Thus, the depreciation of Indian currency is leading to an increase in the export earnings from the SAARC countries. 
3. The J-curve pattern is visible in the Figure 3 especially from 2008 to 2015. The Indian exchange rate in 2008 was 43.50 which depreciated to 48.40 USD in 2009 (World bank data appendix 1), resulting in the worsening of the trade balance till mid 2010 and thereafter it started increasing.

\section{Future Scope:-}

This is a trademark analysis and a stepping stone in the field of trade of India with SAARC as no such analysis has been done before using Marshall-Lerner Condition Approach and the J-curev to validate the international trade driven growth of India from trade with SAARC. Thus, after analyzing the details of India's trade with each SAARC country, the policies can be formed to improve and channelize this trade growth to the maximum possible.

\section{References:-}

1. Fatal, Z., \& Khan, S. (2008). Bilateral J-Curves between Pakistan and Her Trading Partners: Pakistan Institute of Development Economics.

2. Agarwal, Vibhuti.India Considering Financial Incentives for Sugar Exports; Cash-Starved Industry Looking to Cut Huge Stockpiles and Pay Cane Farmers Wall Street Journal (Online) [New York, N.Y] 11 Feb 2015: n/a.

3. Akbostanci, E. (2004). Dynamics of the trade balance: the Turkish J-curve. Emerging Markets Finance and Trade, 40(5), 57-73.

4. Alam, R. (2010). The Link between real exchange rate and export earning: A cointegration and Granger causality analysis on Bangladesh. International Review of Business Research Papers, 6(1), 205-214.

5. Alawattage, U. (2005). Exchange Rate, Competitiveness and Balance of Payment Performance. Staff Studies, 35(1), 63-91.

6. Alexander, S.S. (1952). "Effect of Devaluation on a Trade Balance". International Monetary Fund Staffs, 2, 263 -78 .

7. Antriksha Negi, (2016) . "International Economics Article”. Pratiyogita Darpan, : 85-87

8. Awan, R. U., Shahbaz, M., Sher, F., \& Javed, K. (2012). Does J-curve Phenomenon Exist in Pakistan? A Revisit. Interdisciplinary Journal of Contemporary esearch in Business, 3(9), 1456-1467

9. Bahmani-Oskooee, M. (1985). Devaluation and the J-curve: some evidence from LDCs. The review of Economics and Statistics, 500-504.

10. Bahmani-Oskooee, M. (2001). Nominal and real effective exchange rates of middle eastern countries and their trade performance. Applied Economics, 33(1), 103-111.

11. Bahmani-Oskooee, M., \& Cheema, J. (2009). Short-run and long-run effects of currency depreciation on the bilateral trade balance between Pakistan an d her major trading partners. Journal of Economic Development, 34(1), 19-46.

12. Boyd, D., Caporale, G.M. and Smith, R. (2001). "Real Exchange Rate Effects on the Balance of Trade: Cointegration and the Marshall-Lerner condition". International Journal of Finance and Economics,6:187 200.

13. Brada, J. C., Kutan, A. M., \& Zhou, S. (1997). The exchange rate and the balance of trade: the Turkish experience. The Journal of Development Studies, 33(5) 675-692.

14. Christtopher Dougherty (2007), Introduction to econometrics, ISBN : 0-19-569324-8

15. Dickey, D. A and Fuller, W.A. (1979). "Distribution of Estimators for Autoregessive Time Series with a unit Root". Journal of American Statistical Association, 74: 427 - 431.

16. Dornbusch (1988), The Open Economy: Tools for Policymakers in Developing Countries, ISBN: 13: 9780195207095

17. Eita, Joel Hinaunye (2013) Estimation Of The Marshall-Lerner Condition For Namibia, International Business \& Economics Research Journal, vol. 12,no.5, May, pp. 511-517.

18. Engle, R. F, and Granger, C.W. (1987). "Cointegration and Error Correction: Representation, Estimation, and Testing”. Econometrica, Vol. 50, $987-276$.

19. Faini, R., Pritchett, L. and Clavijo, F. (1988). "Import Demand in Developing Countries". Country Economics Department, the World Bank. WPS 122

20. IMF report 2009 - "The International Trade" , pg 176-198

21. Johansen, S. and Jesulius, K. (1990). "Maximum likelihood estimation and inference on cointegration: with Application to the Demand for Money". Oxford Bulletin of Economics and Statistics 52, $169-210$.

22. Junz H. and Rhomberg R. (1973), "The J-curve, a literature review". American Economic Review, 1973,234265. 
23. Kee, H. L, Nicita, A. and Olarreaga, M. (2004). "Estimating Import Demand and Export Supply Elasticities". Development Research Group, The World Bank, Washington D.C. 20433 USA.

24. Khan, M. S., \& Knight, M. D. (1988). Important Compression and Export Performance in Developing Countries. The Review of Economics and Statistics, 315- 321.

25. Kindleberger, C. (1973). "International Economics. Home wood: Irwin, Inc. Ministry of Finance and Economic Development". Economic Report, various issues. Government Printers.

26. Lal, A. K., \& Lowinger, T. C. (2002). Nominal effective exchange rate and trade balance adjustment in South Asia countries. Journal of Asian Economics, 13(3), 371-383.

27. Lerner, A. P. (1944). "The Economics of Control: Principles of Welfare Economics". The Macmillan Company, N.Y.

28. Maddala, G. S., \& Wu, S. (1999). A comparative study of unit root tests with panel data and a new simple test. Oxford Bulletin of Economics and Statistics,61, 631-652.

\section{Appendix 1 : Exchange Rate of India}

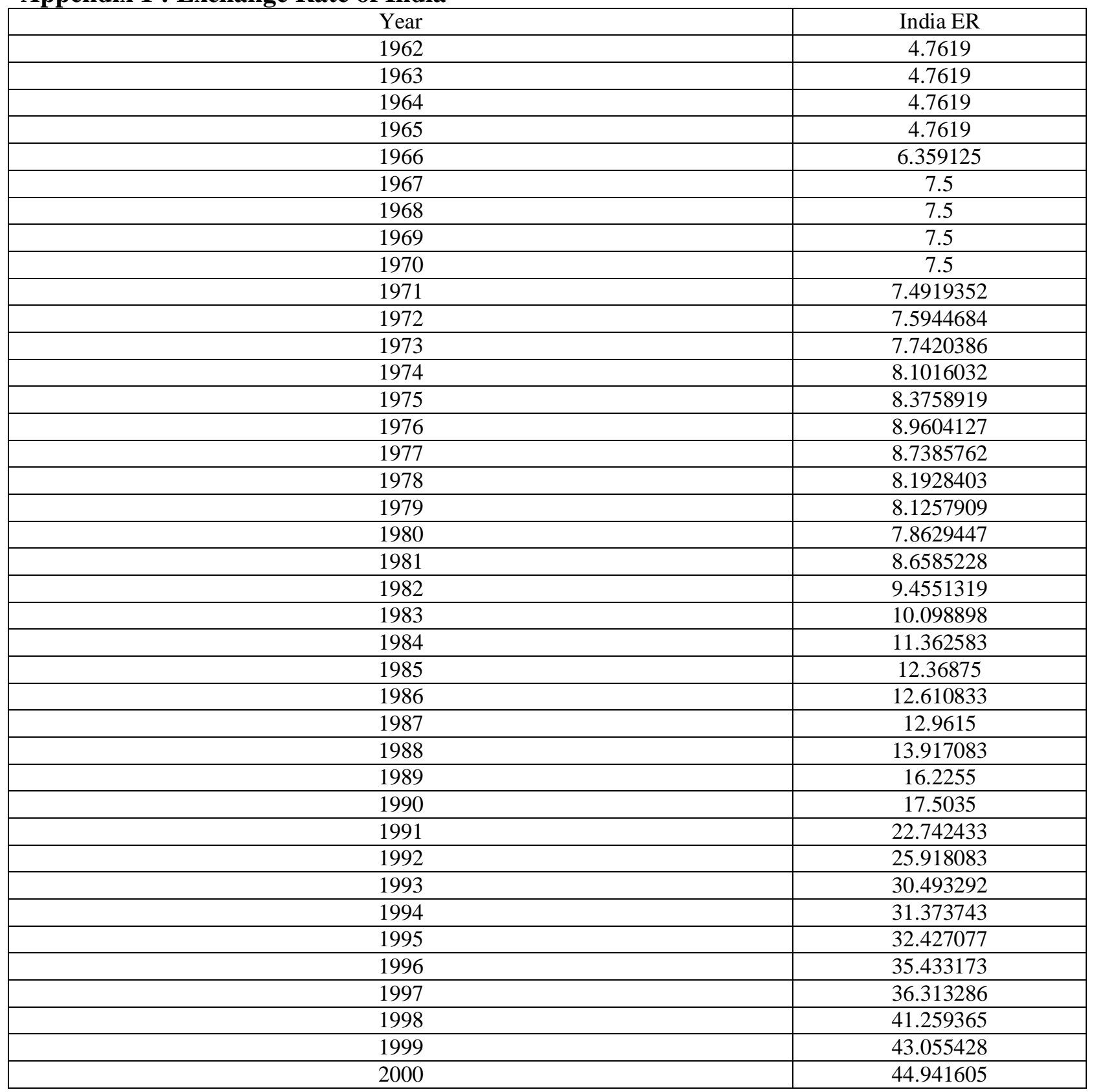




\begin{tabular}{|c|c|}
\hline 2001 & 47.186414 \\
\hline 2002 & 48.610319 \\
\hline 2003 & 46.583284 \\
\hline 2004 & 45.316467 \\
\hline 2005 & 44.099975 \\
\hline 2006 & 45.307008 \\
\hline 2007 & 41.348533 \\
\hline 2008 & 43.505183 \\
\hline 2009 & 48.405267 \\
\hline 2010 & 45.725812 \\
\hline 2011 & 46.670467 \\
\hline 2012 & 53.437233 \\
\hline 2013 & 58.597845 \\
\hline 2014 & 0 \\
\hline 2015 & 0 \\
\hline
\end{tabular}

Source: World Bank data 